\title{
A NEW GENUS \\ AND TWO NEW SPECIES OF \\ COPEPOD PARASITIC ON FRESHWATER FISHES
}

\author{
By G. A. BOXSHALL
}

INTRODUCTION

THE distribution of known species of lernaeid parasites of freshwater fishes in the Old World is notably patchy, with the majority of species known either from Africa or from eastern Asia. Between these two foci, in the region extending from India to the Mediterranean Sea, relatively few species have been recorded. It is probable that this paucity merely reflects the lack of fieldwork in this region; thus the discovery of two new species, one from Iraq and the other from India, belonging to a new genus of lernaeid comes as no surprise.

\section{DESCRIPTION OF NEW GENUS AND SPECIES}

PSEUDOLAMPROGLENA gen. nov.

Diagnosis. Lernaeidae. First pedigerous somite partially incorporated into cephalothorax. Second to fourth pedigerous somites distinct, each subdivided into anterior and posterior portions by a transverse groove. Genital complex comprising fused fifth pedigerous somite and genital somite. Genital apertures on dorsal surface of genital complex. Maxilla 2-segmented, inflated distal segment bearing single claw medially. Maxilliped small, flattened and lying in groove posterior and lateral to maxilla; 3-segmented with terminal segment bearing weak setiform spine(s) medially. Maxilliped bases connected by fleshy ridge. Thoracic legs I-4 biramous, with 3-segmented exopod and 2-segmented endopod. Leg 5 a simple lobe with 2 apical setae. Parasitic on gills of freshwater teleosts. Male unknown.

Type species $P$. annulata sp. nov.

\section{Pseudolamproglena annulata sp. nov.}

(Figs Ia-g, 2a-e)

Diagnosis. Body cylindrical and distinctly segmented (Fig. Ia, b). Cephalothorax broad, dorsal surface concave in holotype, comprising $20-25 \%$ of total body length. Anterior portion of first pedigerous somite incorporated into cephalothorax ; posterior portion free, rounded dorsally and narrower than both cephalothorax and second pedigerous somite. Second to fourth pedigerous somites separated by intersegmental sutures and subdivided into anterior and posterior portions by a transverse groove. Thoracic legs located anterior to groove. Thoracic somites increasing in size posteriorly. Genital complex small, narrower than fourth 

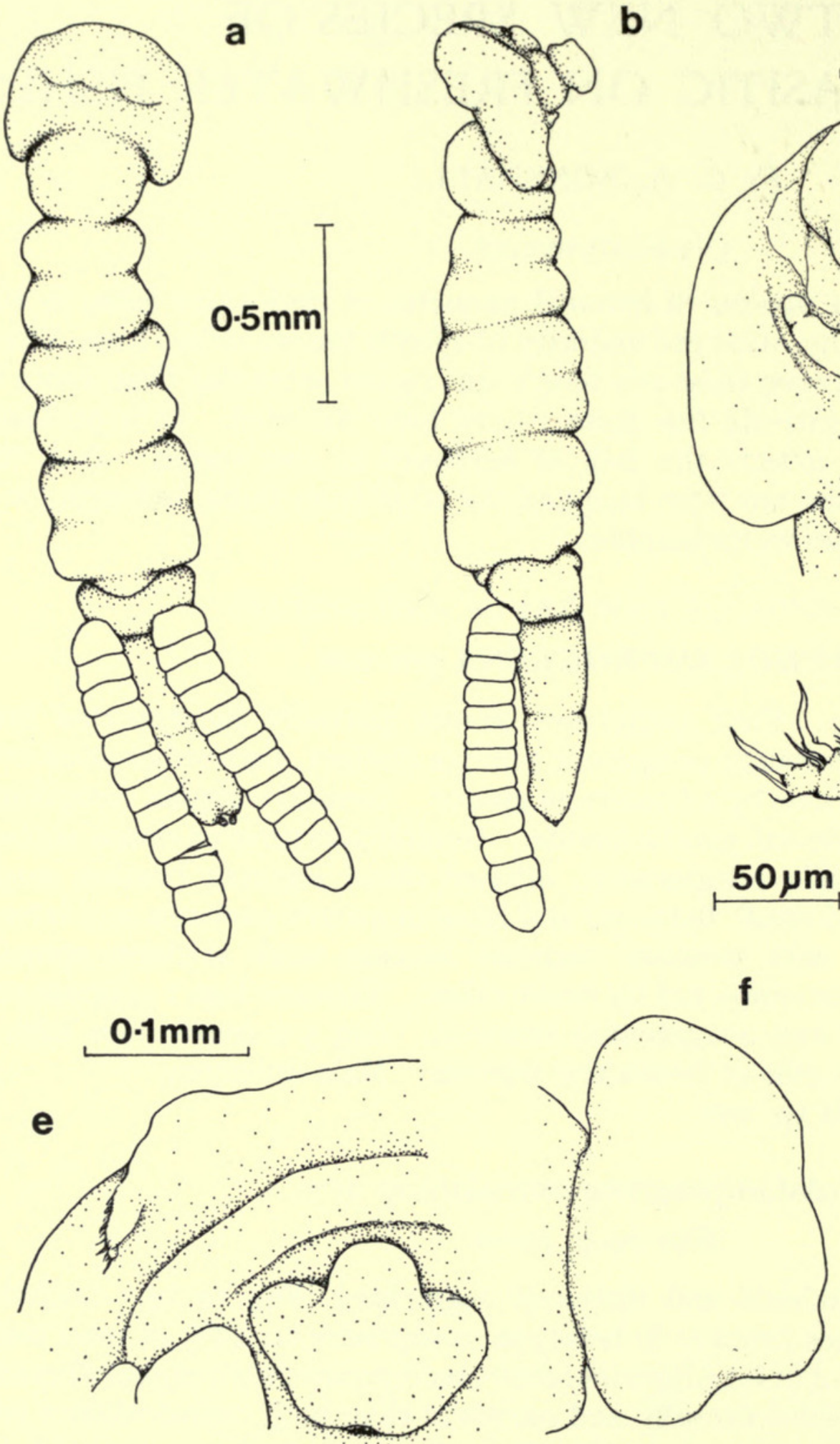

b
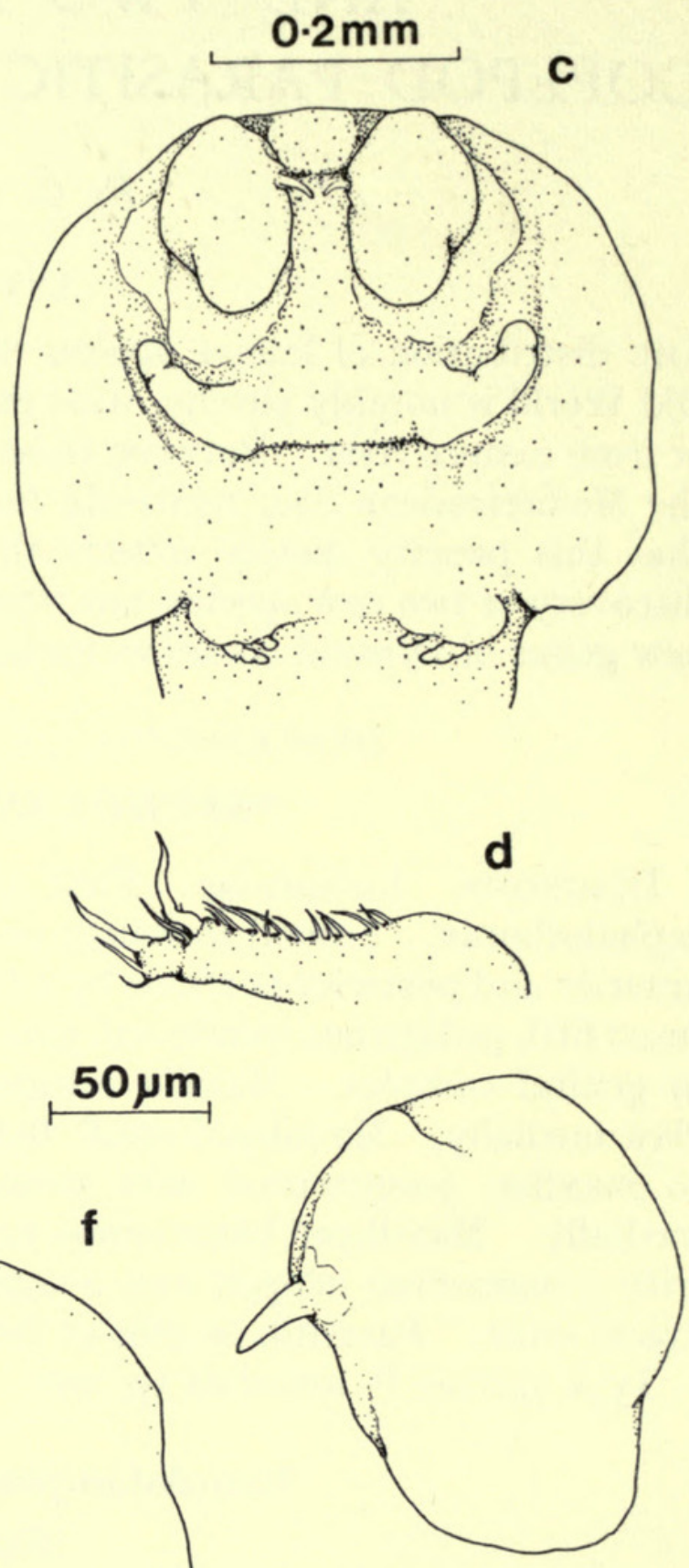

g

FIG. I. Pseudolamproglena annulata sp. nov. female: (a) dorsal entire; (b) lateral entire ; (c) cephalothorax, postero-ventral ; (d) antennule, ventral ; (e) oral region, ventral ; (f) maxilla, lateral ; (g) maxilla, ventral. Bar scale : a, b, o.5 mm ; c, o.2 $\mathrm{mm}$; e, o.I mm; d, f, g, $50 \mu \mathrm{m}$. 
pedigerous somite and with genital apertures situated dorso-laterally. Abdomen elongate, consisting of 2 indistinctly divided somites. Posterior margin of anal somite bilobed bearing medially directed furcal rami. Total body length from $\mathrm{I} \cdot 74$ to $2 \cdot 20 \mathrm{~mm}$, with a mean of $\mathrm{I} \cdot 97 \mathrm{~mm}$ (based on 2 specimens).

Egg strings uniseriate, containing up to I4 eggs. Eggs maturing in oviduct visible through body wall of second to fourth pedigerous somites.

Antennule (Fig. Id) situated on ventral surface near anterior margin of cephalothorax, directed postero-laterally. Segmentation obscure with only the apical segment clearly delimited. Armature comprising I4 setae on anterior margin of proximal segment, 4 setae on distal segment and 2 aesthetasc-like structures, one on each segment. Antenna apparently absent.

Oral region occupied by large trilobed structure (Fig. Ie), probably representing the labrum, anterior to which lies a transverse ridge. Maxillule absent. Maxilla (Fig. If, g) 2-segmented, proximal segment providing a broad base for swollen, gobular distal segment. Entire surface of distal segment ornamented with minute tubercles. Single, dorsally curved spine present on medial surface of segment. Maxilliped inconspicuous, dorso-ventrally flattened and lying in a groove in cephalothorax (Fig. Ic, 2a). Indistinctly 3-segmented with a broad base, elongated middle segment and subquadrate terminal segment; single setiform spine located on medial surface. Maxilliped bases connected by ridge of tissue.

Thoracic legs I-4 (Fig. 2b, c) similar, biramous. Sympod projecting from body surface, bearing single seta lateral to exopod base. Endopod indistinctly 2-segmented, exopod 3-segmented. Leg I armature comprising 2 unequal setae at tip endopod, 2 at tip exopod and I lateral spine on basal segment of exopod. Legs 2-4 unarmed apart from I lateral spine on basal segment of exopod. Leg 5 (Fig. 2e) a simple process with 2 apical setae.

Furcal ramus bearing 4 setae (Fig. 2d) ; I on lateral margin, I on medial margin and I at each posterior corner. Two small papillae present on distal margin.

EтумоLogy. The generic name proposed indicates a close affinity to the genus Lamproglena Nordmann. The specific name alludes to the very distinct segmentation in this species.

Material examined. Type material 2 ovigerous if. Holotype $q$ reg. no. I975.800; paratype reg. no. I975.80I deposited in the collections of the British Museum (Natural History). The material was obtained from the gills of Cyprinion macrostomus (caught in the river Tigris at Mosul, Iraq) present in the British Museum (Natural History) collections. Additional material : 5 우, all either damaged or incomplete, collected by $\mathrm{Mr} Z$. I. Fattohy from the gills of $C$. macrostomus from the same locality. Three of these specimens donated to the British Museum (Natural History) by Mr Fattohy and Dr M. H. Kasim (Mosul University).

Pseudolamproglena simplex sp. nov.

(Figs 2f-i, 3a-d)

Diagnosis. Body segmentation and tagmosis as in P. annulata but less distinct and without intersegmental sutures between the pedigerous somites (Fig. 2f, g). 

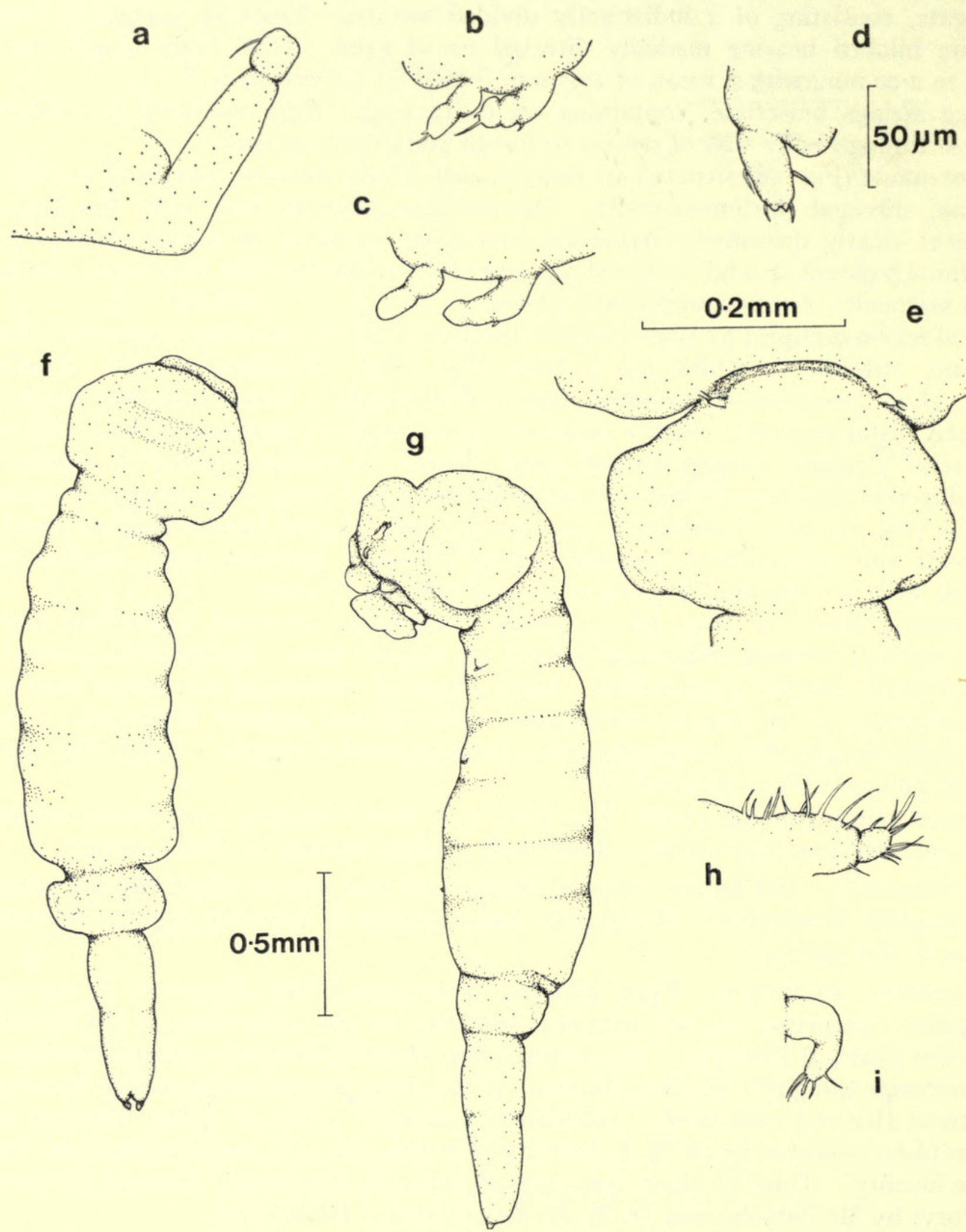

Fig. 2. Pseudolamproglena annulata sp. nov. female: (a) maxilliped, ventral ; (b) leg I, ventral; (c) leg 4, ventral; (d) furcal ramus, ventral; (e) genital complex, ventral. Pseudolamproglena simplex sp. nov. female: (f) dorsal entire ; (g) lateral entire ; (h) antennule, ventral; (i) antenna, lateral. Bar scale: a-d, h, i, $50 \mu \mathrm{m}$; e, $0.2 \mathrm{~mm}$; f, g, $0.5 \mathrm{~mm}$. 

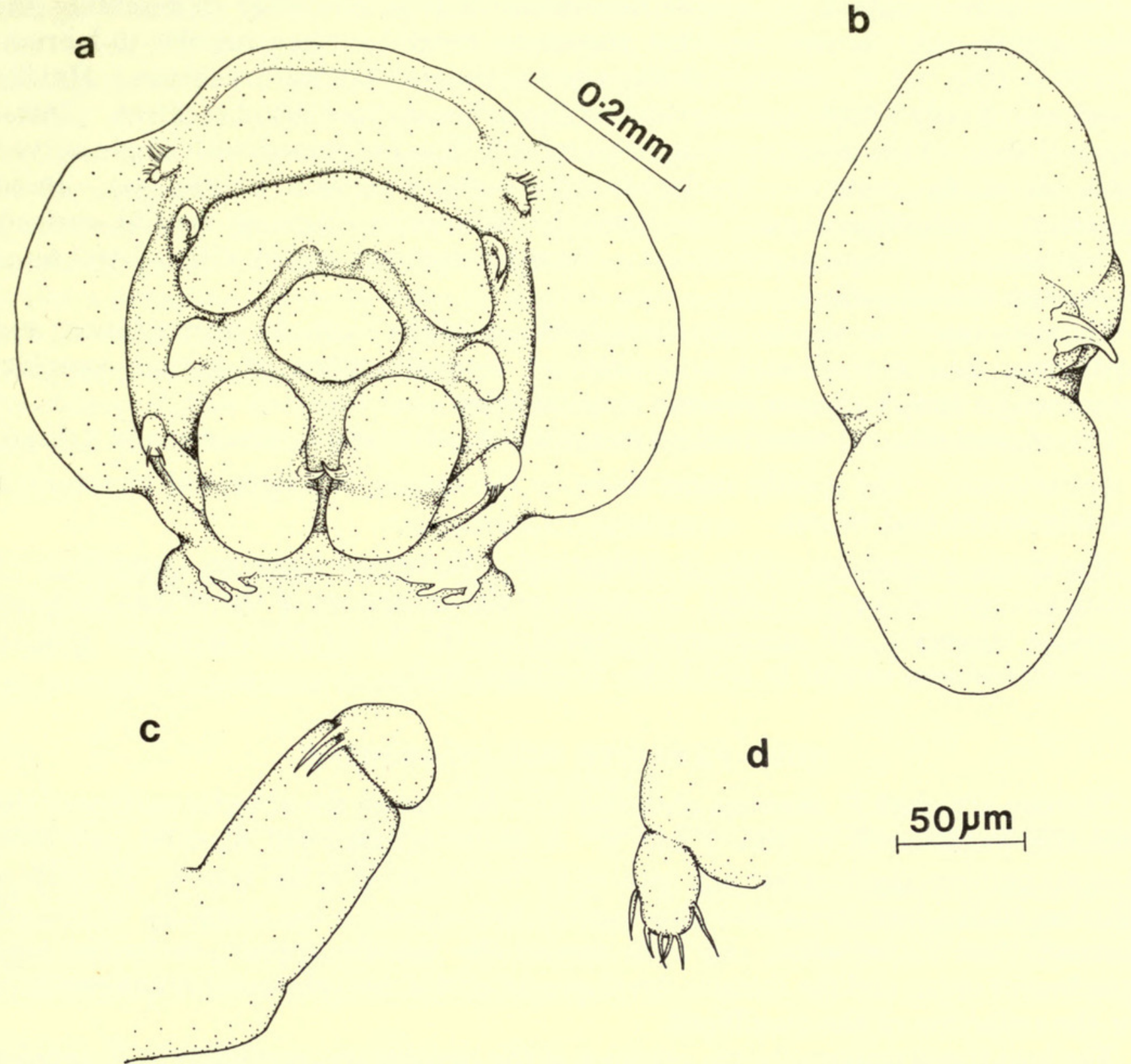

\section{$50 \mu \mathrm{m}$}

Fig. 3. Pseudolamproglena simplex sp. nov. female: (a) cephalothorax, ventral ; (b) maxilla, ventral; (c) maxilliped, ventral; (d) furcal ramus, ventral. Bar scale : a, $0 \cdot 2 \mathrm{~mm} ; \mathrm{b}-\mathrm{d}, 50 \mu \mathrm{m}$.

Cephalothorax comprising about $20 \%$ of total body length. Cephalothorax with prominent anterior ridge visible from the dorsal aspect. Second to fourth pedigerous somites similar in width. Genital complex of holotype (a gravid female) with conspicuous dorsal swellings marking the genital apertures. Total body length from I.93 to $2.45 \mathrm{~mm}$, with a meản of $2.25 \mathrm{~mm}$ (based on 5 specimens).

Only I specimen ovigerous, egg string containing 20 eggs. Mature eggs in oviduct visible in second to fourth pedigerous somites.

Position of all cephalic appendages illustrated in Fig. 3a. Antennule 2-segmented (Fig. 2h) ; large basal segment bearing Io setae on anterior margin and I on posterior margin, apical segment armed with 8 setae and an aesthetasc-like structure. Antenna (Fig. 2i) curved posteriorly, indistinctly 2 -segmented and carrying an apical armature of about 5 setae. 
Oral region occupied by simple hemispherical lobe, probably representing the labrum (Fig. 3a). Transverse ridge present on ventral surface anterior to labrum. Maxillule (Fig. 3a) an unarmed fleshy process situated lateral to labrum. Maxilla 2-segmented with broad basal segment and massive, inflated distal segment. Distal segment (Fig. 3b) marked by transverse constriction and armed with single curved spine on medial surface. Maxilliped indistinctly 3-segmented (Fig. 3c). Basal segments of maxilliped pair connected by transverse ridge on ventral surface. Middle segment elongate, cylindrical. Terminal segment armed with 2 basal setae on postero-medial surface.

Thoracic legs I-4 similar to those of $P$. annulata both in segmentation and armature. Leg 5 positioned anteriorly on ventral surface of genital complex, comprising a simple process bearing 2 apical setae.

Furcal rami (Fig. 3f) armed with 6 marginal setae; I lateral, I medial and 4 distal.

Eтymology. The specific name refers to the simple, hemispherical structure of the lobe in the oral region.

Material eXamined. 6 우 (I ovigerous). Holotype $q$ reg. no. I975.803; 5 paratypes reg. nos I975.804-808. deposited in the collections of the British Museum (Natural History). All specimens collected by Mr M. K. Jyoti from the gills of Labeo diplostomus caught in Dal Lake, Kashmir, India.

\section{HOST-PARASITE RELATIONSHIPS}

The two attached $P$. annulata observed were located on the anterior surface of the posterior hemibranch of gills 2 and 3. A single primary gill filament had been grasped between the maxillae and secured by the insertion of the spines. $P$. simplex attaches to the host in an identical manner but nearer to the distal tip of the gill filament than $P$. anmulata. In both species the maxilla appears to be the only attachment organ and the massive development of this limb presumably compensates for the reduction of the maxilliped.

The host tissue response to the presence of the parasite was negligible in $P$. simplex infections. Different degrees of epithelial hypertrophy were observed associated with the two specimens of $P$. annulata, with a localized, minor response in one case and, in the other, a massive response which resulted in the parasite being completely enclosed by host tissue to the level of the genital complex. It has been suggested (Sproston et al., I950) that envelopment of the parasite provides additional security to the attachment of the parasite.

REMARKS

The new genus can be readily assigned to the subfamily Lamprogleninae of the family Lernaeidae. Of the two other genera in this subfamily, Lamproglena Nordmann and Lamproglenoides Fryer, the new genus is more closely allied to the former. Although the genus Lamproglena comprises a quite heterogeneous group of species the two new species could not be included within this genus without an unacceptable broadening of the generic diagnosis. The genus Pseudolamproglena is 
erected to contain these two species which form a well-defined group distinguishable from species of Lamproglena by the structure and armature of the maxillae and maxillipeds and by their distinctive somitic segmentation.

Fryer (I968) recognized several evolutionary trends within the Lernaeidae. Amongst these are the suppression of external signs of segmentation and tagmosis, the development of a 'neck', reduction of antennules and antennae and the reduction of the number of terminal spines on the maxilliped. Pseudolamproglena exhibits a mosaic of primitive and advanced characters with respect to these trends. It retains a primitive degree of external somitic segmentation and tagmosis combined with the specialized condition of the maxilla and maxilliped and, in $P$. annulata, with the apparent absence of the antenna. This combination of characters suggests that Pseudolamproglena diverged from the ancestral Lamproglena-like stock at an early date and that specialized adaptations of the mouthparts evolved independently.

\section{ACKNOWLEDGEMENTS}

I would like to thank Dr G. Fryer for his valuable comments on some of these specimens and Dr R. J. Lincoln for his criticism of the manuscript. I am grateful to $\mathrm{Mr}$ Z. Fattohy and Dr M. H. Kasim (Mosul University, Iraq) whose donation first brought $P$. annulata to my attention.

\section{REFERENCES}

Fryer, G. I968. The parasitic Crustacea of African freshwater fishes; their biology and distribution. J. Zool., Lond. $156: 45-95$.

Sproston, N. G., YIN, W. Y. \& HU, Y. T. I950. The genus Lamproglena (Copepoda parasitica). The discovery of the life histories and males of two Chinese species from food fishes, revealing their relationship with Lernaea and of both to the Cyclopoidea. Sinensia, Shanghai (n.s.) $1: 5^{\mathrm{I}-84}$.

DR G. A. Boxshall

Department of Zoology

British Museum (Natural History)

CROMWELl Road

LONDON Sw7 5BD 


\section{$2 \mathrm{BHL}$ Biodiversity Heritage Library}

1976. "A new genus and two new species of copepod parasitic on freshwater fishes." Bulletin of the British Museum (Natural History) Zoology 30, 209-215. https://doi.org/10.5962/bhl.part.2380.

View This Item Online: https://www.biodiversitylibrary.org/item/19510

DOI: https://doi.org/10.5962/bhl.part.2380

Permalink: https://www.biodiversitylibrary.org/partpdf/2380

\section{Holding Institution}

Natural History Museum Library, London

\section{Sponsored by}

Natural History Museum Library, London

\section{Copyright \& Reuse}

Copyright Status: In copyright. Digitized with the permission of the rights holder.

Rights Holder: The Trustees of the Natural History Museum, London

License: http://creativecommons.org/licenses/by-nc-sa/4.0/

Rights: http://biodiversitylibrary.org/permissions

This document was created from content at the Biodiversity Heritage Library, the world's largest open access digital library for biodiversity literature and archives. Visit BHL at https://www.biodiversitylibrary.org. 